\title{
Correction to: Pore Network Modeling of the Effects of Viscosity Ratio and Pressure Gradient on Steady-State Incompressible Two-Phase Flow in Porous Media
}

\author{
Magnus Aa. Gjennestad ${ }^{1}$ (D) $\cdot$ Mathias Winkler ${ }^{1} \cdot$ Alex Hansen $^{1}$ (D)
}

Published online: 9 February 2021

(C) The Author(s) 2021

\section{Correction to: Transport in Porous Media (2020) 132:355-379 https://doi.org/10.1007/s11242-020-01395-z}

In the original publication of the article, the Electronic Supplementary Material was missed.

The correct ESM file is provided in this correction.

Electronic supplementary material The online version of this article (https://doi.org/10.1007/s11242-02001494-x) contains supplementary material, which is available to authorized users.

Open Access This article is licensed under a Creative Commons Attribution 4.0 International License, which permits use, sharing, adaptation, distribution and reproduction in any medium or format, as long as you give appropriate credit to the original author(s) and the source, provide a link to the Creative Commons licence, and indicate if changes were made. The images or other third party material in this article are included in the article's Creative Commons licence, unless indicated otherwise in a credit line to the material. If material is not included in the article's Creative Commons licence and your intended use is not permitted by statutory regulation or exceeds the permitted use, you will need to obtain permission directly from the copyright holder. To view a copy of this licence, visit http://creativecommons.org/licenses/by/4.0/.

Publisher's Note Springer Nature remains neutral with regard to jurisdictional claims in published maps and institutional affiliations.

The original article can be found online at https://doi.org/10.1007/s11242-020-01395-z.

Magnus Aa. Gjennestad

magnus.aa.gjennestad@ntnu.no; magnus@aashammer.net

1 PoreLab and Department of Physics, Norwegian University of Science and Technology,

Trondheim, Norway 